\title{
Gottfried Hoffmanns forsvundne Sønderborgkort og andre kort over byen fra 1650 'erne
}

\section{Af Bjern Westerbeek Dahl}

Et af de ældste kort over Sønderborg er tegnet af den tyske fæstningsingeniør Christoph Heer omkring 1660. Da kortet ikke hidtil har været benyttet i den lokalhistoriske litteratur, og nyere undersøgelser nu viser, at det sandsynligvis bygger på en ældre kortlægning af byen, fortjener det en nærmere beskrivelse.

Kortet måler $313 \mathrm{~mm}$ i bredden og $200 \mathrm{~mm}$ i højden og er i måleforholdet ca. 1:6.850. Det viser en stump af Sundeved, Alssund og hele Sønderborg by med gadenet og markeringer af de offentlige bygninger, slottet med udenværker og grave, kirken og rådhuset. Kortet er omhyggeligt udført, selv om der er en smule skævhed i proportionerne, og det giver et detaljeret billede af byens grundplan med dens gader og stræder. Kortet er konturkoloreret, således at skråningerne ved slottet og kirken er grønne, karréerne $i$ byen røde og vandet blåt.

Sønderborgkortet er indbundet $i$ et foliebind sammen med 21 andre smukke planer over danske og norske fæstninger og byer og findes $i$ Håndskriftafdelingen på Det kongelige Bibliotek i København. ${ }^{1}$ For så vidt er det ikke overraskende, at kortene findes netop dér: Bindet er nemlig forsynet med et prægtigt titelblad med en lang dedikation fra Heer til Frederik 3., der efter modtagelsen har indlemmet det $\mathrm{i}$ sit nygrundlagte bibliotek.

Desværre har Heer ikke dateret sine kort; men da både kortet over Kronborg og Køge afbilder svenskernes udbygninger under 2. Karl-Gustavkrig (1658-1660), må de være tegnet efter fredsslutningen i maj 1660, da man fra dansk side havde kontrol med provinserne og igen kunne inspicere fæstningerne.

For en datering til før krigen taler derimod tilstedeværelsen af de skånske fæstninger Helsingborg, Malmö, Landskrona o.s.v., der gik tabt ved freden i Roskilde i 1658. Ovenikøbet er Halmstad og Varberg i Halland medtaget, skønt de blev svenske allerede ved Brømsebofreden i 1645. Det er derfor troligt, at samtlige kort, der i øvrigt har et enhedspræg med fælles målestok og udførelse, alle er kopier af andre - nu tildels tabte - kortarbejder, hvoraf en del er tegnet på basis af opmålinger fra før krigen. 


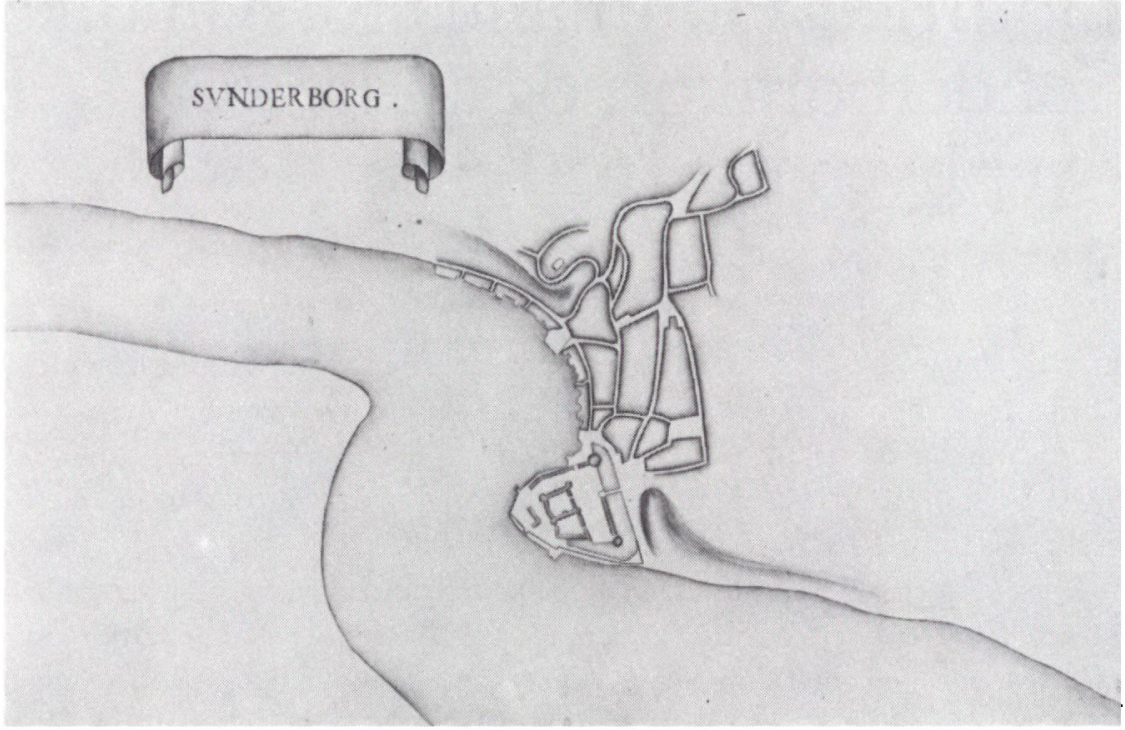

Christoph Heers Senderborgkort fra "Monumentum». (Det kgl. Biblioteks Händskriftafdeling. GKS $\left.716-2^{\circ}\right)$.

Inden der nærmere skal redegøres for forlægget til Sønderborgkortet, vil det være rimeligt at se på Christoph Heers forhold til Danmark.

Vilhelm Lorenzen, der er den eneste, der har beskæftiget sig med fæstningsbyggeriet under Frederik 3., mente, at Heer som fremmed uden nogen tilknytning til Danmark forsøgte at komme i kongens tjeneste omkring 1660 og til det formål tegnede sine 22 kort. $^{2}$ Denne opfattelse blev gentaget $\mathrm{i}$ Weilbachs kunstnerlexikon, hvor Bredo Grandjean skrev om Heer på grundlag af Lorenzens artikel. ${ }^{3}$ Hvordan Heer kunne få fat i sine forlæg, som jo måtte have en vis fortrolig karakter som militærkort, kom Lorenzen dog ikke ind på. Men det $e r$ faktisk muligt at konstatere, at Heeri en årrække var i dansk tjeneste. I en tysk præstehistorie fra 1707 findes en udførlig levnedsbeskrivelse af Heer, ${ }^{4}$ der kan suppleres med nyfundne oplysninger fra Hans Schacks privatarkiv.

Christoph Heer blev født i Lauban i Schlesien (det nuværende Lubán i Slask) i Polen den 16. september 1637 som søn af byens evangeliske ærkediakon Johannes Heer. I 1650'erne studerede han jura og matematik ved universitetet i Leipzig og kom i 1658 til København for at studere fortifikation hos sine fætre, Georg og Gottfried Hoffmann. Fæstningskunstens praksis lærte Heer, da han med Gottfried Hoffmann rejste til Frederiksodde, det nuværende Fredericia, hvor Heer kom til at arbejde som 
konduktør, d.v.s. underingeniør. Heer nævnes da også flere gange i løbet af 1660'erne i Hoffmanns indberetninger til Krigskollegiet. Det fremgår heraf, at Heer i 1662 fik orlov til at rejse til København for at besøge sin bror, lægen Martin Heer, der lige var kommet til byen. ${ }^{5}$ Samtidig skulle han studere Henrik Ruses nyligt påbegyndte byggeri af Kastellet. I foråret 1663 havde han en samtale med Hans Schack om detaljer i Frederiksoddes befæstning, og i 1665 ledede Heer byggeriet af fæstningsbroen over voldgraven ved Strandporten. ${ }^{6}$

Heers fætre må have været gode læremestre, for i 1668 dukker han op som ledende ingeniør ved Strassburgs befæstning, en af det tyske riges vigtigste forsvarsværker mod det dengang aggressive Frankrig. Da byen alligevel i 1681 måtte overgive sig til Louis 14. trods omfattende arbejder ved

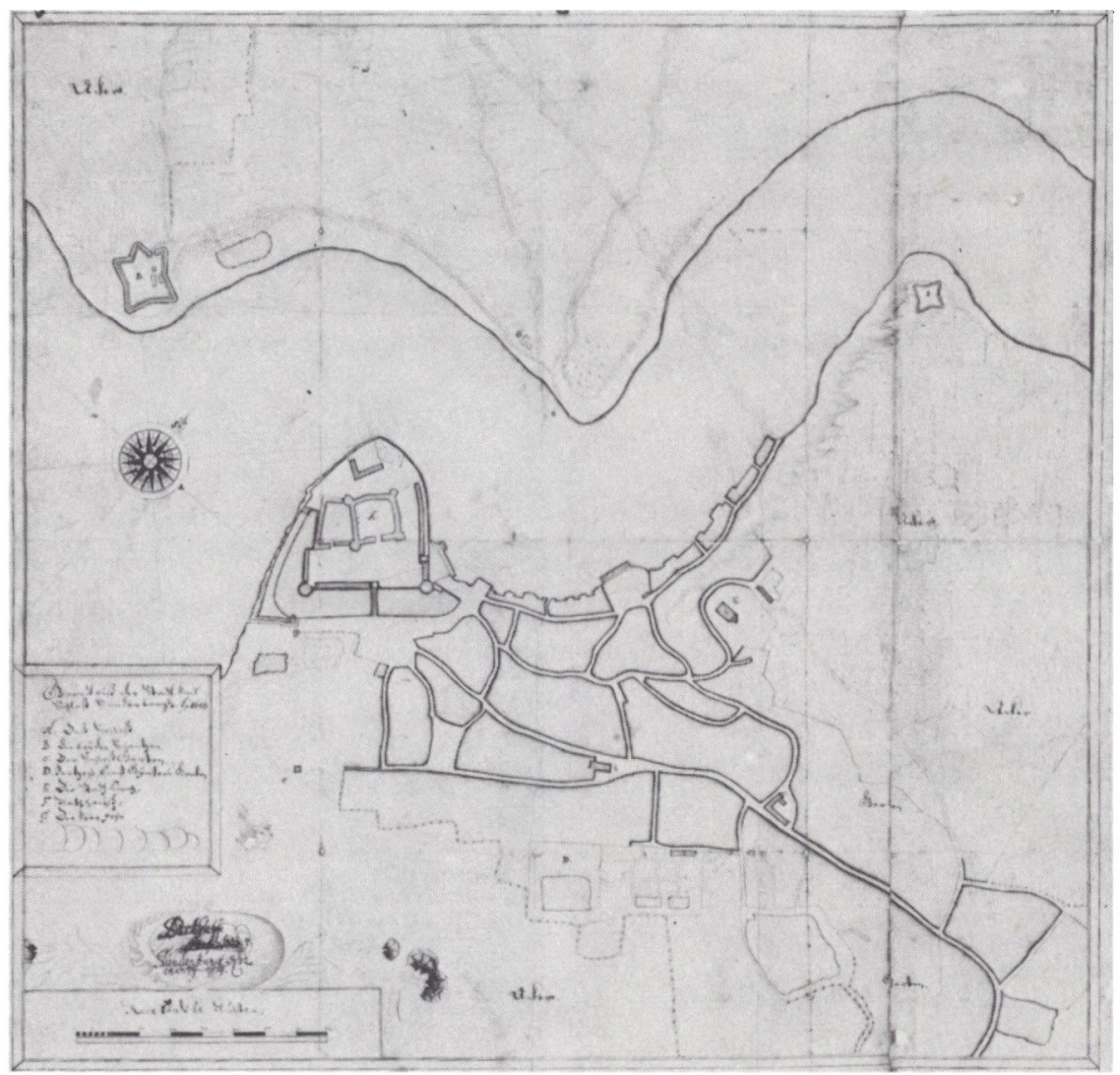

Anonymt kort over Senderborg fra 1658/59. (Det kgl. Biblioteks Händskriftafdeling, GKS 717-2. nr. 50). 
fæstningsanlæggene i det foregående tiår, måtte Heer flygte. I de følgende år var han ingeniør ved bl.a. Heidelbergs befæstning og i Frankfurt am Main. I 1689 udgav han en begynderbog $i$ fortifikation "Theori et Artis Praxis muniendi«, der fire år senere blev efterfulgt af endnu en lærebog "Speculum Artis muniendi“, der bl.a. indeholder en detaljeret gennemgang af Fredericias forhold i 1660 'ernes begyndelse. ${ }^{7}$ Fra 1693 til sin død i 1701 var Heer lærer ved den sachsiske kurfyrste Johann Georg 4.s nygrundlagte kadetskole i Dresden.

Under et af sine ophold i København må Heer altså have tegnet sine kortkopier, herunder Sønderborgkortet.

Det er ikke svært at finde et beslægtet kort over byen. Ligeledes i Håndskriftafdelingen på Det kongelige Bibliotek findes en plan over Sønderborg fra $1659 .{ }^{8}$ Kortet måler $475 \mathrm{~mm} \times 453 \mathrm{~mm}$ og er i måleforholdet ca. 1:2.740. Det er koloreret med rødt, blåt og grønblåt og er delvis udført som en pennetegning med brunt. Kortet har to titelfelter - det ene (i det firkantede felt) med titlen: "Grundtriss der Stadt Undt Schloss Sunderborghs An 1658 " og med et index, der henviser til syv bogstavbetegnende lokaliteter på kortet. Oven over feltet med målestokken findes en delvis makuleret signatur i løvramme, der muligvis kan tydes som "... Dietleff ... kens". Herunder findes en datering "Sunderburg dn 12 Martij [1]659 . Dateringen $1658 \mathrm{i}$ titelfeltet er formodentligt påført kortet for at markere tidspunktet for den tilstand, kortet skulle vise, mens selve dateringen 1659 betegner året for tegnearbejdet.

Lighedspunkterne med Heers kort er påfaldende, men - som det kan ses er der også forskelle: Heers kopi har på den nordlige spids af halvøen, hvorpå slottet ligger, en skibbro, og sydøst for slottet er der antydet en dalsænkning. Ingen af disse oplysninger findes på 1659-kortet.

Heers kort er som omtalt meget omhyggeligt udført, og der er ingen grund til at tro, at hans kort skulle indeholde oplysninger, der ikke har været på forlægget. Derfor må 1659-kortet afvises som forlæg for Heers kopi. Men det er tydeligt, at der har været et fælles forlæg. Ikke alene er der trods de omtalte forskelle stor indre lighed, men Heers kort er i præcis $2 \frac{1}{2}$ gange måleforholdet af 1659-kortet (1:2.740 i forhold til 1:6.850). Det kan kun skyldes, at de to kort har haft et fælles forlæg, som har dannet grundlag for en formindskelse eller forstørrelse af måleforholdet på de to kopier i forhold til originalen, hvis måleforhold vi ikke kender.

Ligesom Christoph Heers kort minder om kortet fra 1659, har begge kort stor lighed med det kobberstik, som Erik Dahlbergh lod stikke til sin store biografi over Karl den 10. Gustavs bedrifter.

Erik Dahlbergh var født i 1627, og kun tretten år gammel blev han ansat 
som skriver ved den svenske administration i Pommeren og allerede på dette tidspunkt indledte han sin omfattende historisk-topografiske tegnevirksomhed. Men først da han i 1647 blev konduktør i Demmin i Pommeren fik han egentlig tegneundervisning. Under et studieophold i Frankfurt am Main fra 1650-54 stiftede han bekendskab med den topografiske maler og kobberstikker Matthäus Merian d. y. og leverede forlæg for flere af dennes kobberstik til "Theatrum Europæum “. Samtidig modtog Dahlbergh undervisning af ingeniøren Andreas Böckler i fortifikation, geometri og perspektivlære, og han fik således en solid basis for sin egen virksomhed. Ved krigsudbruddet i 1656 rejste Dahlbergh til den svenske hær i Polen og var under Karl-Gustav-krigene generalkvartermesterløjtnant i den svenske hær. Under felttogene udnyttede han sine evner som tegner i rigt mål, og han nåede at få tegnet et meget stort antal kort og prospekter. Dahlberghs planer om at udnytte sit materiale til et stort illustreret værk om Karl den 10. Gustav blev taget op af den svenske formynderregering i 1663, da man afkøbte Dahlbergh hans tegninger. I de følgende år lå materialet dog hen, bl.a. fordi man endnu ikke havde fundet frem til en forfatter til teksten; men i 1667 begyndte i Paris stikningen $i$ kobber af nogle af de mange tegninger. Med afbrydelser i 1670'erne og 1680'erne afsluttedes arbejdet af kobberstikkeren Willem Swidde i Stockholm i årene fra 1688-90. Først i 1696 udkom "De rebus a Carolo Gustavo... « med en omfattende tekst af den tyske jurist og historiker Samuel von Pufendorf og med 124 kobbertavler.

Dahlbergh arbejdede selv med billedmaterialet i flere perioder efter krigen. Han sammentegnede, rentegnede og omarbejdede mange af sine kladder fra krigen og indhentede oplysninger om vigtige begivenheder, han ikke selv havde deltaget i. Hvorledes Sønderborgkortet er blevet til, ved vi desværre ikke og den opmåling omkring byen, som Dahlbergh selv omtaler i sin dagbog, må henvise til afstikningen af de svenske skanser på Sundeved og ikke en egentlig opmåling af byen. ${ }^{10}$ En kladdetegning til kobberstikket har været eftersøgt uden held i de svenske biblioteker og arkiver, og den må nu anses for tabt.

Kobberne til Pufendorfs værk blev som omtalt for en stor del stukket $\mathrm{i}$ Frankrig af datidens dygtigste kobberstikkere. Desværre er Sønderborgkortet heller ikke signeret, men i Bibliothèque National i Paris formoder man, at det er udført af kobberstikkeren Noël Cochin (f. 1622 - muligvis d. efter 1685). Kortet hører i så fald til den gruppe plancher, der blev sendt til Paris i 1667 og som Dahlbergh selv ledede stikningen af. Rammen er dog muligvis udført af datidens førende ornamentstikker Jean Le Pautre. ${ }^{11}$

Dahlberghs forlæg fortaber sig således i uigennemtrængelighedens mørke; men det er sandsynligt, at han har benyttet sig af det danske kortmateriale, 


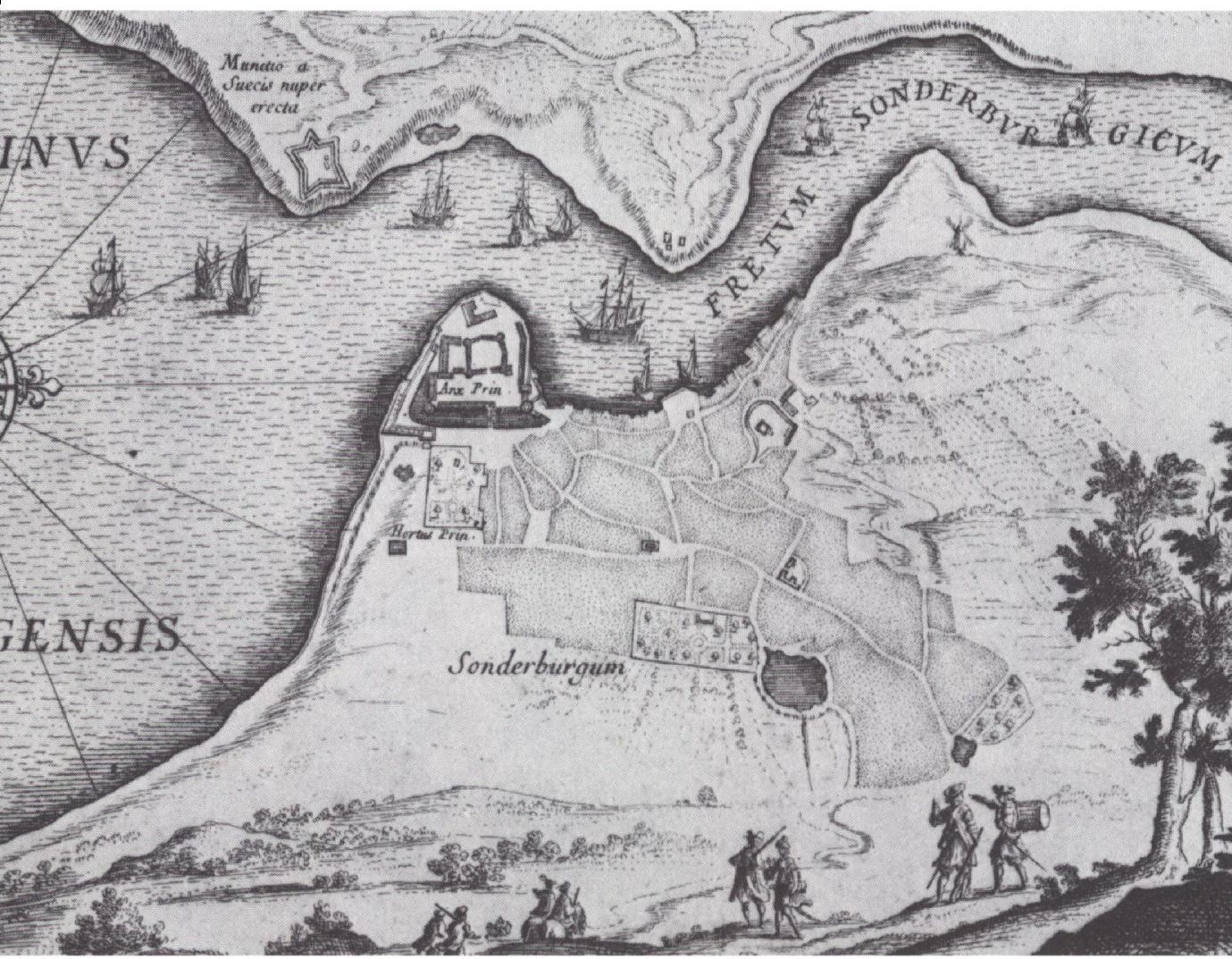

Udsnit af kobberstik af Samuel von Pufendorfs De rebus a Carolo Gustavo... gestis, Nürnberg 1696, muligvis stukket af Noël Cochin efter Erik Dahlbergs kladdekort over Sonderborg omkring 1667. (Her gengivet efter losblad i Det kgl. Biblioteks kortsamling).

som han har kunnet få fat på i Sønderborg. At han skulle have rekvireret kort fra Danmark efter krigen - som han gjorde med visse polske tegninger - synes derimod ikke sandsynligt. Endnu mindre rimeligt forekommer det, at Dahlberghs nu forsvundne kladde skulle være forlægget for det anonyme 1659-kort og Heers kort.

Det er derimod mere rimeligt at tænke sig, at Heer har benyttet et ældre dansk kort og her kommer hans to fætre, Georg og Gottfried Hoffmann, ind i billedet: Vi kender ikke meget til Georg Hoffmanns kortproduktion, der tilsyneladende indskrænker sig til et nu tabt kort over Frederiksodde fra 1649. ${ }^{12}$ Derimod er oplysningerne flere omkring Gottfried Hoffmanns kortlægninger, selv om hans arbejder fra disse år kun kan følges indirekte. 
Den 21. januar 1661 søgte han Krigskollegiet om at få afregning for $\sin$ løn $i$ de foregående fire år. Her næuner han, at han før krigen har foretaget "Auffmessung der meisten Vestungen ${ }^{13}{ }^{13}$ I en liste over Krigskancelliets kortsamling fra 1680 opremses ialt 43 kort over danske byer og landsdele, heraf var de 20 tegnet af Gottfried Hoffmann. Blandt de byplaner han havde tegnet var bl.a. Ribe, Kolding og Varde; men der er i listen ingen oplysninger om noget Sønderborgkort. ${ }^{14}$ Alligevel er det ikke urimeligt at forestille sig, at Hoffmann også har aflagt Sønderborg et besøg.

Gottfried Hoffmann var kommet til Danmark omkring 1647, og efter at have været under broderens "strenge kommando ${ }^{15}$ indtil 1651, arbejdede han ved Frederiksoddes befæstning til 1653, hvor han blev udnævnt til ingeniør og forflyttet til Skåne. Her blev han tilknyttet Helsingborg fæstning, hvor han opholdt sig til krigsudbruddet i 1657. Under 1. Karl-Gustav-krig udnævntes han til kaptajn og deltog under Axel Urup i felttoget i Skåne i vinteren 1657/58. Efter Roskildefreden kaldtes han til København, hvor han befandt sig under belejringen og bl.a. havde opsyn med den københavnske vandforsyning. Efter krigen blev han i 1661 igen ingeniør i Frederiksodde. ${ }^{16}$ Imellem sine mange gøremål har Hoffmann altså rejst land og rige rundt og foretaget opmålinger af $i$ hvert fald de fleste danske fæstninger. Desværre er kun ganske få af hans kort bevaret. På Det kongelige Bibliotek i København findes bl.a. et Nakskovkort og et kort over Bornholm fra 1650'erne, der begge har stor ydre lighed med Hoffmanns kort over Frederiksodde. Selv om Hoffmann kun sjældent signerede sine kort, har han - som det er påvist andetsteds - benyttet en helt speciel teknik, som røber ham: Selve kortbilledet har han tegnet $\mathrm{i}$ hånden og koloreret på sædvanlig vis; men navneoplysningerne har han ofte ladet trykke ind på kortet med et håndstempel, ${ }^{17}$ Også Christoph Heer har anvendt denne "typetrykteknik ", som det også kan ses af titlen på hans Sønderborgkort og de øvrige kort i håndskriftet.

Der synes dog ikke at være bevaret noget Sønderborgkort fra Gottfried Hoffmanns hånd. Men det betyder naturligvis ikke, at han ikke kan have været i Sønderborg i løbet af 1650'erne og dér tegnet et kort over byen. Dette kort kan have været i Hoffmanns kortsamling, som vi kender lidt til fra et brev fra Hoffmann til Hans Schack, dateret Frederiksodde 24. marts 1663. Det ses heraf, at Hoffmann har fået ordre til at tegne et kort over København og sende det ind til Krigskollegiet så hurtigt som muligt. Da Hoffmann på dette tidspunkt ikke havde arbejdet ved Københavns befæstning i over halvandet år, kan det kun betyde, at han har haft en kortsamling, som også Krigskollegiets præsident kendte og værdsatte. At der også heri har været genparter af Hoffmanns tidligere kortproduktion synes højst sandsynligt. ${ }^{18}$ $\mathrm{Og}$ at disse kort har været kendt - og er blevet kopieret af Gottfried 
Hoffmanns fætter og nærmeste arbejder, Christoph Heer, må være hævet over enhver tvivl.

Det kan heller ikke udelukkes, at den sønderborgske hertug har haft en genpart af kortet, som Erik Dahlbergh har fået fat på under krigen og således har kunnet benytte som forlæg for sit kort til Pufendorfs værk. I andre tilfælde ved vi, at Dahlbergh har kendt til dansk kortmateriale: Da svenskerne i oktober 1657 erobrede Frederiksodde, fik de samtidig fat i de danske projekter til byen - måske det ovennævnte kort af Georg Hoffmann fra 1649. Det er i hvert fald den eneste forklaring på, at Dahlbergh kunne udsende sit Fredericiakort med indtegnede gadelinier og kanalforløb, der aldrig kom længere end til tegnebrættet.

Også 1659-kortet kan have sine oplysninger fra Hoffmanns kort eller genparten af det $i$ det hertugelige arkiv, selv om tegneren selv har suppleret forlægget med svenskernes skanser fra september 1657.

Det er derfor sandsynligt, at den anonyme tegner i 1659, Christoph Heer og Erik Dahlbergh alle bygger på en eller flere genparter af et nu forsvundet kort over Sønderborg, tegnet af Gottfried Hoffmann i 1650 'erne.

\section{NOTER}

1. Det kongelige Bibliotek. Håndsk riftafdelingen. Gammel kongelig Samling. 716-2 $2^{\circ}$ Efter titelbladet kaldes det ofte "Monumentum ".

2. Vilhelm Lorenzen: Problemer i Kobenhavns Historie 1660-1757 belyst ved samtidige Kort. Historiske Meddelelser om København, 3. række, 5. Bind, København 1942-43, s. $173 \mathrm{ff}$.

3. Weilbachs Kunstnerleksikon, 1. Bind, København 1947, s. 497.

4. G. Hoffmann: Lebens-Geschichte aller evangelischen Pastorum Primariorum, die ... in ... Lauban gelehret und geleben haben, Lauban 1707, s. 194-215.

5. Om Martin Heer se: August Hirsch: Biographisches Lexikon der hervorragenden Ärzte aller Zeit und Völker, Band 3, Berlin 1931, s. 117.

6. Rigsarkivet. Privatarkiver. Hans Schack, 6262, A 1, Breve fra Gottfried Hoffmann, 26/8/1662, 15/9/1663; breve fra Dietrich Busch, 30/5/1665 og 6/6/1665.

7. Behandlet i: Bjørn Westerbeek Dahl: Christoph Heers beskrivelse af Fredericia fra 1660'erne. Vejle Amt Årbog 1981, Vejle 1981, s. 72-86.

8. Det kongelige Bibliotek. Håndskriftafdelingen. Gammel kongelig Samling, 717, nr. 50.

9. Samuel von Pufendorf: De rebus a Carolo Gustavo...gestis, Nürnberg 1696. Oplysningerne i det følgende om Erik Dahlbergh bygger på: Börje Magnusson: Svenska teckningar: 1600-talet: en konstbok frản Nationalmuseum, Stockholm 1980, s. 45ff.

10. Dahlbergh omtaler under den 10. september 1657: "[Til Sønderborg] hwarest jag afstack nagre wärk så och een Skantz opå Jutlanske sidan wedh innlopet för hamnen “. (Erik Dahlberghs Dagbok (1625-1699) utgifven med indledning af Herman Lundström. Uppsala 1912, s. 110 .

11. Bibliotheque Nationale: Inventaire du fond français: Graveurs du XVIII ${ }^{c}$ siecle par R.-A. Weigert, vol. 3, Paris 1954, s. 85; Börje Magnusson: Anf. arb., s. 56.

12. Erik Housted: Til rigernes forsvar, gavn og bedste: Fredericia som garnisonsby i 300 år, Fredericia 1979, s. 11. 
13. Rigsarkivet. Landetaten. Krigskollegiet. Indkomne breve 1661. Brev fra Gottfried Hoffmann $21 / 1 / 1661$.

14. Rigsarkivet. Landetaten. Krigskancelliet. Indkomne sager 1680, nr. 326.

15. Som 13.

16. Se Bjørn Westerbeek Dahl: Anf, arb., s. 83.

17. Se Bjørn Westerbeek Dahl: Ophavsmanden til Daniæ-Norvegiæ-kortet i Det kongelige Biblioteks Kortsamling. Fund og Forskning 1982.

18. Som 6. Brev fra Gottfried Hoffmann, 24/3/1663. 
